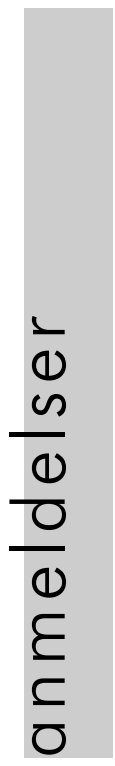

\section{Modernitetens idéhistorie}

Sven-Eric Liedman: I skyggen of fremtiden. Modernitetens idéhistorie, Gads Forlag 2000, 619 sider, 299 kr.

Den svenske idéhistoriker Sven-Eric Liedman har skrevet en omfangsrig bog om modernitetens idéhistorie. Han kalder den: I skyggen af fremtiden modernitetens idéhistorie. Værket, der er på 619 sider, er skrevet over en årrække fra begyndelsen af 90'erne med Sovjetunionens kollaps og stridighederne mellem modernister og postmodernister som udgangspunkt. Striden behandles forskellige steder og på forskellig måde værket igennem. Ingen tvivl om, at den har spillet en stor motiverende rolle for projektet. Direkte kommer det frem ved at Liedman har opdaget, at kontroversen f.eks. eksponeret ved Habermas contra Lyotard ofte var en kontrovers, der havde samtidsbestemmelsen (samtidsdiagnosen) på programmet og $\mathrm{i}$ fokus, på samme gang som kombattanterne og deres eftersnakkere hele tiden trak på et historisk arsenal, som aldrig blev ekspliciteret. Det er i høj grad en sådan eksplikation, som ganske vist ikke kan være udtømmende eller altdækkende endsige nondisputabel, men som alligevel kan og skal være mere end illustrativ og rent subjektivistisk, Liedman har sat sig for at rekonstruere. Et prisværdigt projekt. Ikke mindst fordi han undgår en af tidens store farer $\mathrm{i}$ denne genre, nemlig at bygge påstande op på mere eller mindre (og oftest det sidste) plausible psyko-historiske påstande. Men han glemmer aldrig udgangspunktet, nemlig stridighederne i nutidens kontroverser omkring hvad der helt overordnet er karakteristisk for vor tid og hvor vi evt. mener, at vi bevæger os hen.

Bogen er upolemisk uden styring via kæpheste, informativ, bund solid, somme tider overraskende, præget af et væld af rimelige og velfungerende distinktioner (hvad der måske er dens største styrke), og så er den skrevet i et helt ukrukket sprog. Den er vel næppe det skarpeste, hvad angår standpunktmarkering eller filosofisk spidsfindighed, til gengæld er den sober som bare fanden, og den formidler et overblik over modernitetens idéhistorie, som ingen anden publikation gør det. Målet: at kaste lys over modernitetens idéhistorie er indfriet. For bogen handler ikke kun eller overvejende om ideer om det moderne, men derimod om ideer i det moderne. Hertil kommer, at den rummer en gedigen oversigt over samtidsdiagnostiske positioner fra de sidste 50 år. Liedman vil næppe komme til fornærme nogen med denne bog, til gengæld kan han oplyse mange. Bogen er uden tvivl skrevet $i$, hvad man kunne kalde en oplyst ånd, der er selvoplyst.

\section{II}

Liedman skriver altså modernitetens idéhistorie. En mere rammende og lidt mere ydmyg titel ville nok have været "træk af modernitetens idéhistorie«, for skønt bogen rummer imponerende meget, såvel i tidshistorisk dybde, som $\mathrm{i}$ tematisk bredde, så er der (selvfølgelig) også områder, som ikke er med eller 
kun berørt yderst perifert (f.eks. teologiske spidspositioner $\mathrm{i}$ det tyvende århundrede, bortset fra befrielsesteologien, der kort er omtalt; kunsten er ganske vist ikke glemt, men dog stedse betragtet distanceret og udefra og reduceret til æstetik; og hele modernitetmetafysikkomplekset er kun glimtvist strejfet).

Men hvad er modernitet? I stikordsforklaringen i bogen lyder det om modernitet: »den proces som påbegyndtes i Europa i senmiddelalderen eller 1500tallet og som kommer til udtryk i handel, urbanisering, statsvæsen, videnskabelig og politisk tænkning, teknik, kunst, filosofi osv.« Så er der i hvert fald ikke sagt, hverken for lidt eller for meget. Men der gives et vink om et vigtigt træk, nemlig at modernitetsbegrebet hos Liedman er ret omfattende såvel i tid som i fænomenberøring. Heldigvis tager Liedman dog udgangspunkt i den franske oplysningstænker Condorcets fremtidsforhåbninger, når modernitetens projekt skal kontureres. Heldigvis, fordi der hermed kommer en fokusering ind $\mathrm{i}$ billedet, som er vigtig, nemlig drømmen om via oplysning at tilvejebringe en fremtid, hvor menneskets evne til at skabe historien netop markeres som det afgørende. (Intet steds ses det så tydeligt, at Liedman er arvtager af oplysningstraditionen end her, hvor han markerer ideen om historieskabelse, men aldrig problematiserer den). Oplysningsprojektet gik, kunne man sige, hos Condorcet ud på at skabe modernitet, og det vil sige menneskeligt skabt og kontrolleret fremskridt $\mathrm{i}$ menneskenes forhold til naturen, deres forhold til hinanden og til sig selv. Som Liedman gør opmærksom på var der andre samtidige bud, der var mindre dristige og mere varsomme. Det gælder Kant, det gælder Hume, det gælder Adam Smith. (Og det gælder også Burke, som Liedman ikke gør meget ud af, skønt han i sine bedste stunder demonstrerede et respektaftvingende kritisk modspil til oplysningsprojektet). Et af de afgørende varsomhedssignaler, som Kant nok var den forste til at markere, kommer til udtryk ved, at han insister på, at der ikke er nogen udviklingsautomatisk enhed mellem naturbeherskelsens logik og moralen. Det har bl.a. den implikation, at fremskridtsbegrebet ikke sådan uden videre kan anvendes generelt. Hos Liedman fører det til en vigtig distinktion, nemlig mellem hård og blød oplysning. Den er for såvidt anlagt, eller antydet allerede hos Kant, men i tidens løb er den blevet helt nødvendig. Og ikke så få, for at sige det litotisk, af modernitets- og civilisationskritikkerne fra det sidste århundrede er bygget op over denne dobbelthed i modernitetsprojektet. Ikke sjældent i form af, at det hævdes, at der er indbygget en nærmest udvejsløs konflikt mellem de to former for oplysning. Stort set al tysksproget modernitetskritik er spundet over denne figur, hvor pointen er, at den hårde oplysning ikke bare ikke løber parallelt med den bløde, men den ødelægger den. Kontroversen kom på fuldt blus i begyndelsen af 1900-tallet med sociologernes distinktion mellem kultur og civilisation, og tilsvarende Gemeinschaft-Gesellschaft. Deb løb ind over Max Weber og Spengler, fort- 
satte i den gamle Frankfurterskole og parallelt hermed hos Heidegger for så at munde ud i Habermas' distinktion mellem system- og livsverden. Men er det tyvende århundredes modernitetskritikker oftest spundet over spaltethedsfiguren, så var det nittende århundredes teorier for tilbedelse af moderniteten til gengæld oftest netop helt blinde overfor denne dobbelthed.

Den hårde oplysning omfatter naturvidenskab, teknologi, teknik, de dele af samfundsvidenskaberne der er styrings- og administrativt orienterede samt større dele af økonomien. Det karakteristiske for denne oplysning er, at den er baseret på kvantifikationer, har klare succeskriterier, er globalt ensartet og kumulativ. Den bløde oplysning derimod omfatter store dele af humanvidenskaberne, moral, (demokrati) religion og kunst. Her er der i overvejende grad tale om kvalitative størrelser, som ikke sådan uden videre lader sig kvantificere, lige som succeskriterier er mindre bastante (hvis de overhovedet forekommer eller er plausible). Ejheller er der nogen global ensartethed og talen om kumulativ vækst eller udvikling er ofte ren nonsens.

Man kan diskutere, hvor heldig benævnelsen hård contra blød oplysning er. F.eks. kunne man indvende, at en sådan distinktion har en tendens til at afhistorisere, al den stund distinktionen uden problemer kan anlægges universalhistorisk. Man kunne også indvende, at selve den radikale oplysningsidé kommer til at lide under, ja bliver amputeret ved distinktionen. Men hvad enten benævnelsen er heldig eller ej, så er distinktionen helt afgjort nødven- dig. Modernitetsprojektet har altså to motorer, en hård og en blød oplysning - og spørgsmålet er, hvordan de to motorer har kunnet arbejde sammen eller om de tværtimod har modarbejdet hinanden.

Nu kunne man tro, at Liedman med denne distinktion i ærmet ville oprulle et i modernitetskritikker ofte forekommende scenario, hvor blød og hård oplysning generelt stilles i konfrontation. Men det overraskende ved hans fremstilling er, at det netop ikke gøres. Han undersøger forskellige institutioner: "skoler", videnskabs- og etikinstitutionerne, æstetik og teknologi samt politik og religion. I begyndelsen af bogen gøres der opmærksom på, at sammenligningen af forskellige institutioner, som normalt ikke bindes sammen, kan være frugtbar, fordi der herved kan blotlægges sider af oplysningsprocessen, som normalt overses eller negligeres. Her - i disse institutioner og hvor de mødes - er der sjældent tale om direkte konfrontation mellem hård og blød oplysning, men langt oftere tale om indflettethed og på mange måder uproblematisk gensidig understøttelse. Tillige viser det sig, at der i praksis forekommer "omslag" - forstået på den måde, at hvad der i udgangspunktet teoretisk eller ideologisk er hård oplysning kan vise sig at alliere sig ganske godt med en blød, samtidig med at bløde strategier kan indgå venskab med nok så hårde. Liedmans tilgangsvinkel demonstrerer, at relationaliteten mellem blød og hård oplysning er langt mere kompliceret, end den blotte distinktion i sig selv lader ane. Fremstillingen af "instituti- 
onerne" (bogens anden del), er meget informativ og interessant netop på grund af dobbeltheden mellem hård og blød oplysning, som på forskellig vis mødes i praksis. Den gamle marxist viser her sin ideologikritiske kunnen og viden.

Første institution, der undersøges er skolen ('Lære for livet'). Afsnittet rummer en god historisk oversigt over uddannelsesinstitutioner og uddannelsesideologi fra 1700tallet og frem til i dag. Ikke mindst er der en solid gennemgang af Wilhelm von Humboldts universitetsidé, samt de praktiske problemer denne idé havde (og har).

Næste kapitel har overskriften "Det sande og det gode". Overordnet er det forholdet mellem videnskabsinstitutionen og etik/religion-institutionerne fra 1700tallet og frem til 1990'erne som er i brændpunktet. Der indledes med en række distinktioner og etymologiske udredninger omkring ordene "praktisk", "teknisk", "videnskabelig", "ideologi" etc. Generelt er dette kapitel i lange stræk mere diskuterende, problematiserende og stillingtagende end det forudgående. Der beskrives en bevægelsesbue fra bestræbelser på at bygge etik på videnskab til at dette projekt anfægtes og går i opløsning, samtidig med at selve videnskabsbegrebet nærmest eksploderer og mister en række af de hidtil selvfølgelige konnotationer. Der er rimelige historiserende markeringer omkring Comte, Spencer, Max Weber, Nietzsche, Tolstoy, Wienerkredsen, Wittgenstein og Keynes, men til slut bliver det temmelig summarisk, og at der ofres tre sider på
Derridas Marx-bog forekommer mig besynderligt.

Så følger et kapitel om "artefakterne". Det handler om teknik og kunst eller teknologi og æstetik. Der er en tese om, at teknologi og æstetik i starten af det moderne adskilles for at blive selvstændige "videnskaber", for så i dag at glide mere og mere sammen. Atter er der en lang og for så vidt informativ redegørelse for begreberne æstetik, kunst, teknik, teknologi osv. Kapitlet rummer mange informationer og afliver nogle gængse myter (f.eks. at det nittende århundrede entydigt var besat af fremskridtstro; og at Hegels idé om kunstens død skulle være en idé om, at den så ikke længere kunne eksistere $\mathrm{i}$ det moderne). Men helt generelt virker kapitlet lidt løst. Det er som om det forhold, at Liedman ikke rigtigt har et synspunkt - eller et eller andet, han vil forsvare eller kritisere - nok sikrer, at han atter er en solid fremstiller af informationer, der til gengæld bliver uden egentlig pointe. Vi får meget lidt at vide om, hvad der faktisk sker i kunsten, derimod en del at vide om, hvad der er fremsat i metateorier over kunst. Der er en tendens til, at der både er for meget og for lidt: for meget, fordi det er relativt tilfældigt, hvad der formidles samtidigt med, at der ikke fremsættes nye synspunkter; og for lidt fordi der savnes ordentlige nedslag i værker. "Den guddommelige politik" er overskriften på det ottende kapitel om institutionerne politik og religion. Der tages fat på problemet omkring politikkens status fra middelalderen og frem til i dag. Udgangspunktet er det i moderniteten anlagte projekt om at gøre poli- 
tikken til religionens erstatning, både i form af afskaffelsen af religion og politik som redskab til indfrielsen af forjættelsen om paradis på jorden. Liedman peger - traditionelt - på to kilder til denne idé om den guddommelige politik, nemlig den jødisk kristne tradition med dens historieforjættelse (ganske vist primært som sakral historie) og så politikkens fuldstændige sækularisering med Machiavelli. Der tages udgangspunkt i middelalderen hos Joachim af Fiore, hvor der artikuleres forventninger om et nyt tusindårsrige. $\mathrm{Og}$ det søges vist/hævdet, at hans tænkning har givet impulser til bondeoprørenes messianisme. Det vises, hvordan aggressiv ateisme dukker op i forbindelse med Den franske Revolution, hvor politikken nu for første gang helt skal erstatte religion. Interessant er gennemgangen af Saint-Simons og Comtes forhold til religion og deres forsøg på at skabe en såkaldt moderne religion. Punktvist gås der ind på fascismen og stalinismen (uden at der er noget at skrive hjem om i denne fremstilling). Og der sluttes med en påpegning af, at i dag ser det ud til, at politikken ikke længere nogen steder udstyres med messianske forhåbninger. Snarere tværtimod. Som sådan er en af modernitetens grundimpulser definitivt lagt på hylden. Og her har postmodernisterne altså ret. Kapitlet har på en og samme tid karakter af at formidle mange indsigter og virke lidt tilfældigt. Det gælder allerede udgangspunktet hos Fiore. Det havde sikkert været nok så informativt at tage de klare tendenser, som er i selve skolastikken, i retning af sækularisering.
Den er jo klart anlagt i universaliestriden, i ændringerne i forståelsen af skabelsesmysteriet, i udviklingen af opfattelsen af fornuften og endelig i hele omvæltningen $i$ sacerdotium et regnum-konflikten, hvor der allerede i middelalderen (hos Marsilius af Padua) sker en sprængning af fundamentet, som havde været gældende siden Augustin. Det er også lidt underligt, at den eneste teologiske position som nævnes i moderniteten er befrielsesteologien fra 1960'erne og 70'erne.

\section{III}

Inden afsnittet om institutionerne er der - efter at der i indledningen er gjort rede for selve projektet, markeret distinktioner og fremlagt motiver for fremstillingen - et længere afsnit (første del) om fremkomsten af nye tids- og rumsforståelser, samt menneskeopfattelser fra middelalderen og frem til i dag. Udgangspunktet er den gamle traver om det mekaniske ur og alle dets kulturelle, disciplinerende og organiserende konsekvenser (vel første gang markeret hos Lewis Mumford i Technics and Civilization, 1934). Mest interessant $\mathrm{i}$ afsnittet forekommer Liedmans fremstilling af, hvordan rum og tidsforestillingerne nok ændrer sig, men med store "forsinkelser" indbyrdes. Sådan, at da man efter den naturvidenskabelige revolution stod med et grænseløst rum, var opfattelsen af tiden stadig i det store og hele meget begrænset og bundet til Bibelens skabelsestid. Det vil sige alt $i$ alt omkring 6000 år for jorden. En anden konsekvens af denne binding til bibelsk tid var, at man gik ud fra, 
at mennesket var af samme alder som jorden. Først sent i moderniteten blev historien udvidet om ikke til det grænseløse, så dog til det uoverskuelige, og tilsvarende blev menneskets tid adskilt fra jordens oprindelse. Sagt på en anden måde: det tog meget lang tid før (historisk) tidsopfattelse blev lige så moderne som rumsopfattelsen. Og det havde selvfølgelig en række konsekvenser, ikke mindst for historieskrivningen. $\mathrm{Og}$ for menneskeopfattelsen, som sidste kapitel i dette afsnit er helliget. Kapitlet rummer meget, men der gås sjældent i dybden. Og der tages ikke stilling. Vi præsenteres for den klassiske førmoderne opfattelse af mennesket, som noget historisk uforanderligt. En opfattelse, som, kan det tilføjes, også havde moderne fortalere, f.eks. Hume. Derefter følger et væld af positioner - moderne positioner - der alle, hvad enten de bygger på racelære, klasseteori, nationalisme, evolutionisme, biologisme eller psykologisme, har det ved sig, at de mener, ja går ud fra, at mennesket er et væsen, som i sin grund ændrer sig historisk. Der er nævnt modpositioner, f.eks. stumper af fænomenologien og eksistentialismen, men der gås ikke i dybden. Hvad der f.eks. tilskrives Heidegger er ikke andet end et generationstypisk meningsreservoir (som Habermas udtrykker det). Resultatet bliver, at en af modernitetens største illusioner, nemlig at det moderne menneske er helt forskelligt fra tidligere mennesker, får lov til stort set at stå som en selvfølgelighed. Dog ikke helt uden problemer, for sjovt nok viser det sig jo, at en sådan alhistoriserende antropologi på flere måder kommer i konflikt med en anden af modernitetens ideer, nemlig universalismen.

\section{IV}

Bogens tredje del har selve bogens titel som overskrift, nemlig "I skyggen af fremtiden". Dets første kapitel har en interessant redegørelse for en dobbelttendens i moderniteten, nemlig på den ene side Entzauberung, som Max Weber nok teorihistorisk er kendt for, men som - viser Liedman - kulturhistorisk fik sit egentlige gennemslag med Franz Rosenzweigs Der Stern der Erlösung fra 1921. Entzauberung eller mistet trolddomsglans/affortryllelse er et generaliseret udtryk for, at livsprocesserne i det moderne ikke længere ses som underkastet magiske og ukontrollerbare kræfter, men tværtimod hviler i rationaliseringsbestræbelser, som i princippet ligger inden for menneskets kontrolmuligheder. Affortryllelsen har meget ofte (hvad Liedman ikke eksponerer) været sammenkoblet med en idé om det moderne som en historisk erkendelsespashøjde. $\mathrm{Nu}$ og for første gang blev mennesket virkelig i stand til at se verden, som den var. Parallelt med affortryllelsen løb imidlertid også en anden opfattelse, nemlig en som peger på den moderne verdens fortryllelse (Verzauberung). Synspunktet (som findes hos Baudelaire og til dels hos Benjamin) bygger på en fascination af og somme tider begejstring for de kroniske skift og forandringer, som sker i det moderne. Sjovt nok har Liedman fisket betegnelsen Verzauberung frem fra Heideggers meget dunkle og monstrøse og først for nyligt offentliggjorte værk fra 30'erne Beiträge zur 
Philosophie. Det er vel unødvendigt at tilføje, at betegnelsen hos Heidegger ikke står for noget positivt. Efter lidt polemik mod Heidegger begynder fortryllelsesbegrebet at tage form hos Liedman. Det angiver det forhold, at der i det moderne trækkes veksler på fremtiden uden at der er dxkning for dem (s. 463) - fremtiden som opium. I øvrigt er der her angivet, hvad der ligger til grund for bogens titel.

Efter at fortryllelsesbegrebet er fastlagt følger nogle påvisninger af træk i medicinhistoriens fremtidsforventninger samt de planetariske rumfantasier, der blev sat i værk med rumfarten.

Det næste kapitel har overskriften "Europæerne og de andre". Nu er det forholdet mellem europæerne og de andre, samt ikke mindst, europæernes selvforståelse i dette møde fra middelalderen og frem, som er under luppen. Fremstillingen er her ofte mere kulturhistoriografisk end idéhistorisk (og anderledes kan det heller ikke være med så brede penselstrøg). En af pointerne er, at der er noget særegent ved europæernes sammenkobling af teknik/ økonomi og så politik/etik. Det særegne er, at de to størrelser er blevet søgt forbundet i det europæiske, hvorimod det ikke har været tilfældet (i noget, der bare minder herom) i andre kulturkredse (det nordamerikanske hører selvfølgelig ind under, hvad der her kaldes det europæiske). Egentlig er dette bare en understregning af, at modernitetsprojektet som helhed og enhed - hvor skrøbeligt end - af hård og blød oplysning $i$ et universalistisk perspektiv hidtil i det store og hele har været et vestligt fænomen. I og for
Vesten. For det vises - med harme hvordan projektet af europæerne blev forvaltet, dvs. helt glemt, i Afrika, hvor der ikke var antydning af forsøg på at overføre projektet, kun undertrykkelse og udplyndring - i øvrigt ofte støttet af racistiske ideer. Der lægges op til, hvad bogens sidste kapitel nu eksplicit skal tematisere, nemlig: er vestlig universalisme andet end et forelsket selvportræt, som man kan dyrke ved højtidelige begivenheder, men som man lige så let kan glemme alt om, dersom det er i ens egen interesse?

I slutkapitlet genfremsættes bogens afgørende distinktion mellem blød og hård oplysning, og visse karakteristiske og historiske erfaringer med eller aftryk af dem eksponeres. Hvad tiden har vist sammenfattes i to hovedkonklusioner: 1) at modernitetsprojektet (som enhed hård og blød oplysning) lige fra starten har haft sine kritikere, hvilket har medvirket til en vis grad af selvkorrektur. (Konklusionen må siges at være rimelig, men den står dog $\mathrm{i}$ et lidt underligt lys $\mathrm{i}$ forhold til hele fremstillingen, hvor modpositioner $\mathrm{i}$ forhold til oplysningsprojektet alt for sjældent belyses ordentligt). 2) Der findes ikke bare et modernitetsprojekt, men utallige. For ganske vist er den hårde oplysning universel eller global, ensartet og kumulativ, men den er altid sammenkoblet med kulturelt specifikke bløde "oplysninger". (Jeg markerer oplysning i anførselstegn, for her viser det sig, at der kan være problemer med benævnelsen hård kontra blød oplysning. Begrebet blød oplysning tenderer nu i retning af ideologi samtidig med at det afhistoriseres). $\mathrm{Og}$ 
selv om det ville være meningsløst at forsøge at ændre den hårde oplysnings logik, så er dens generelle indstilling og dens koblen sig sammen med blød "oplysning" foranderlig. Her ramler Liedman selvfølgelig ind i spørgsmålet om den bløde oplysnings eventuelle universalisme. Det ender med en forsigtig idé om, at der er elementer i den bløde (vestlige) oplysning, som ikke kan tænkes bort eller reduceres til kulturel partikularisme - uden at enhver oplysningside gøres til nonsens.

Ellers præsenteres i et upolemisk vue ganske mange modernitetsteoretiske positioner fra de sidste decennier. Godt og informativt. I det hele taget: hvis der er nogen, der har meget travlt med at sætte sig ind i Liedmans værk, så kan de koncentrere sig om afslutningskapitlet. Her er alle principielle spørgsmål stillet - til gengæld må man så undvære de mange historiske informationer. Og så kan det være, at vi er tilbage i det som det er Liedmans bestræbelse at rydde op i, nemlig modernitetsteoretiske markeringer, som trækker på en enorm historisk ballast, men som aldrig ekspliciterer den. Ved vejs ende er det klart, at Liedmans projekt ikke ender i skepticisme, fatalisme, kynisk ironi eller naiv idealisme. Han har et veludviklet blik for, at hans egne oplysningsfilosofiske idealer ofte rummer nok så megen provinsialisme. Men han har også en tro på, at der er elementer i modernitetsprojektet, som ikke kan opgives. Og som ikke bare fremsættes i skyggen af fremtiden, men som dens lys.

Bogen er oversat fra svensk af Gitte Lyngs. Og det er gjort ganske for- trinligt. En lidt dum fejl, der vel er en oversætterfejl, findes på side 444, hvor Adam Smiths metafor om "den usynlige hånd" er blevet til "den usynlige handel". Forhåbentlig er den så graverende, at læserne opdager, at noget er galt og ikke begynder at tænke $\mathrm{i}$ baner a la handel med narkotika.

Til slut et lille suk: bogen er vanskelig at læse, ikke på grund af, hvad der står i den, men fordi den som tyk limet billigbog ganske enkelt hele tiden vil klappe i - bortset fra, når man er omkring midten. Det er nødvendigt hele tiden at være over den men det er besværet værd.

Hans-Jorgen Schanz.

\section{Se Venedig og tænk videre!}

Christian Bank Pedersen: Formens erindringer. Om Thomas Manns Der Tod in Venedig, Skriftserien LAS, Klim 2001, 160 sider, 198 kr.

Det siges, at i Venedig har der altid været nogen, der har skabt kunst, før man selv indfinder sig. Man kan kunstnerisk set kun i svarets form træde ind i Venedig. Det gælder også Thomas Manns Døden i Venedig og i en fordobling forfatteren Aschenbachs ageren i selvsamme roman - og nu tillige Christian Bank Pedersen der skriver en bog om Aschenbach i Venedig, der er om Mann, der skriver i og om Venedig osv., der dog også er om stemmerne "fra det fjerne": Platon, Schopenhauer og Nietzsche. 